\title{
Geophysical study of the easternmost Walvis Ridge, South Atlantic: Deep structure
}

J. GOSLIN Institut de Physique du Globe de Paris, Laboratoire de Géophysique Marine, 4 Avenue de Neptune, 94100, St. Maur-des-Fossés, France J. C. SIBUET Centre Océanologique de Bretagne, B.P. 337, 29273, Brest, France

\section{ABSTRACT}

A seismic-refraction study of the sedimentary structure of the South West African continental shelf was carried out between lat $17^{\circ} \mathrm{S}$ and $24^{\circ} \mathrm{S}$ using expendable sonobuoys. Striking differences exist both in the topography and sedimentary structure between the shelf north and south of the Walvis Ridge. South of the ridge, as far as lat $23^{\circ} \mathrm{S}$, the shelf consists of a prograded series, whereas north of the ridge, at least as far as lat $17^{\circ} \mathrm{S}$, east-trending canyons cut the shelf sedimentary cover. The steep northern scarp of Walvis Ridge can be traced eastward under the sediment of the continental margin. The southern flank of the ridge is buried under a thicker sedimentary cover and could only be traced eastward to long. $10^{\circ} \mathrm{E}$ on seismic-reflection records. This flank probably parallels the northern scarp under the continental margin. Two-dimensional structural models, built with the help of seismic-reflection and seismic-refraction results and based on the hypothesis of local isostatic equilibrium, account for the observed gravity profiles. A compensating root consists of light material (density $2.95 \mathrm{~g} / \mathrm{cm}^{3}$ ) and reaches a depth of about $25 \mathrm{~km}$. Gravity results also suggest that the Walvis Ridge does not constitute a superimposed load on the lithosphere; rather, the ridge and its underlying compensating mass were created at approximately the same time as the adjacent ocean basins.

The creation of the two aseismic ridges of the South Atlantic - the Rio Grande Rise and Walvis Ridge - by a mantle hot spot and plume is accepted; this theory seems to explain most of the peculiar features of the Walvis Ridge. However, it is probable that the surface expression of the mantle hot spot was controlled by the presence of weak zones in the lithosphere such as transform faults. Key words: South West Africa, seismic refraction, geophysics, gravity, mantle plume, transform faults.

\section{INTRODUCTION}

A study of the easternmost segment of the Walvis Ridge, based mainly on seismic-reflection data, was presented in an earlier paper (Goslin and others, 1974). We proposed that the landward termination of the Walvis Ridge consists of two basaltic basement ridges enclosing a 2-km-thick sedimentary basin and probably continuing eastward beneath the sedimentary cover of the continental shelf. We suggested that sediment coming from the south had partially filled the central basin and that the ridge had acted as a dam to any further northward transport of sediment, thus explaining the contrast in sediment cover between the northern and southern flanks of the ridge. The last major tectonic phase that affected the Walvis Ridge area was considered to have coincided with the change of the pole of opening of the South Atlantic Ocean during Late Cretaceous time.

In this paper, we first present a seismicrefraction study of the continuation of the Walvis Ridge beneath the continental shelf of South West Africa. The second part of the paper is devoted to a gravity study of the deep structure of the easternmost segment of the Walvis Ridge. Lastly, we review ideas on the opening of the South Atlantic in the light of our results and propose a hypothesis for the creation of the aseismic ridges of the South Atlantic.

\section{PROLONGATION OF THE \\ WALVIS RIDGE UNDER \\ THE CONTINENTAL SHELF}

Results of seismic-refraction profiles over the South West African continental shelf (Fig. 1) enable us to determine the topography of the acoustic basement, the sedimentary structure of the shelf, and the possible eastward continuation of the structural units of the Walvis Ridge under the continental margin. Considerable differences between the continental shelf north and south of the Walvis Ridge are suggested by the bathymetry and gravity contour map (Figs. 1, 2). The northern continental shelf is narrow and thinly covered with sediment, and its slope is very steep. The southern continental shelf has a great extension and a more gentle slope (Fig. 1), and it is covered with thick sedimentary deposits.

\section{Seismic-Refraction Recording}

Techniques and Data Processing

Seismic-refraction profiling techniques using expendable sonobuoys have previ- ously been described (for example, Houtz and others, 1968). The seismic source aboard R/V Jean Charcot was the Flexotir (Grau, 1969). All profiles were shot with a shooting interval of $30 \mathrm{sec}$ (that is, about every $100 \mathrm{~m}$ ). None of the profiles was reversed. The analog signal from the sonobuoys was recorded on a variable-area film recorder and on magnetic tape, which allowed replays of tape through appropriate filters when necessary (Figs. 3a, 3b).

Although some sedimentary layers are thick, the sonobuoy time-distance graphs show no curved segments to justify use of the Herglotz-Wiechert method (for example, Jobert, 1973). Segments from the different interfaces were therefore considered as straight-line arrivals. Approximate corrections for sloping interfaces were made with the help of continuous-reflection records. The velocity corrections are small, because the slopes of the interfaces are seldom more than $2^{\circ}$ (Fig. 5).

Using oblique seismic-reflection records, Houtz and others (1968) determined seismic velocities ranging from $1.6 \mathrm{~km} / \mathrm{sec}$ to $2.2 \mathrm{~km} / \mathrm{sec}$ in recent sediment in the deep basins of the Atlantic. Direct measurements of compressional velocities of JOIDES samples from abyssal plains and from the Rio Grande Rise area show that the $P$-wave velocities in the upper sediments are lower than $1.64 \mathrm{~km} / \mathrm{sec}$, sometimes reaching values as low as $1.5 \mathrm{~km} / \mathrm{sec}$ (Maxwell and others, 1970b). On the continental shelf, however, higher values have been measured in the upper sedimentary layer. For example, Leyden and others (1972) assumed a velocity of $1.8 \mathrm{~km} / \mathrm{sec}$ for the topmost sedimentary layer of the West African continental shelf from lat $2^{\circ} \mathrm{N}$ to $22^{\circ} \mathrm{S}$.

The sonobuoy results presented in this paper were computed using an assumed velocity of $1.8 \mathrm{~km} / \mathrm{sec}$ for the topmost layer. This velocity was found to give the best fit of depths of refracting horizons with those estimated for recognizable horizons on the seismic-reflection records made over the continental shelf (Fig. 5). The same velocity was also used for the surface sediment over the central basin of the Walvis Ridge, described in a previous paper (Goslin and others, 1974; sonobuoys 13, 14, 15, Fig. 1); this is justified on the basis of the sedimentary transport and deposition mechanism proposed for this area (Goslin and others, 
GOSLIN AND SIBUET

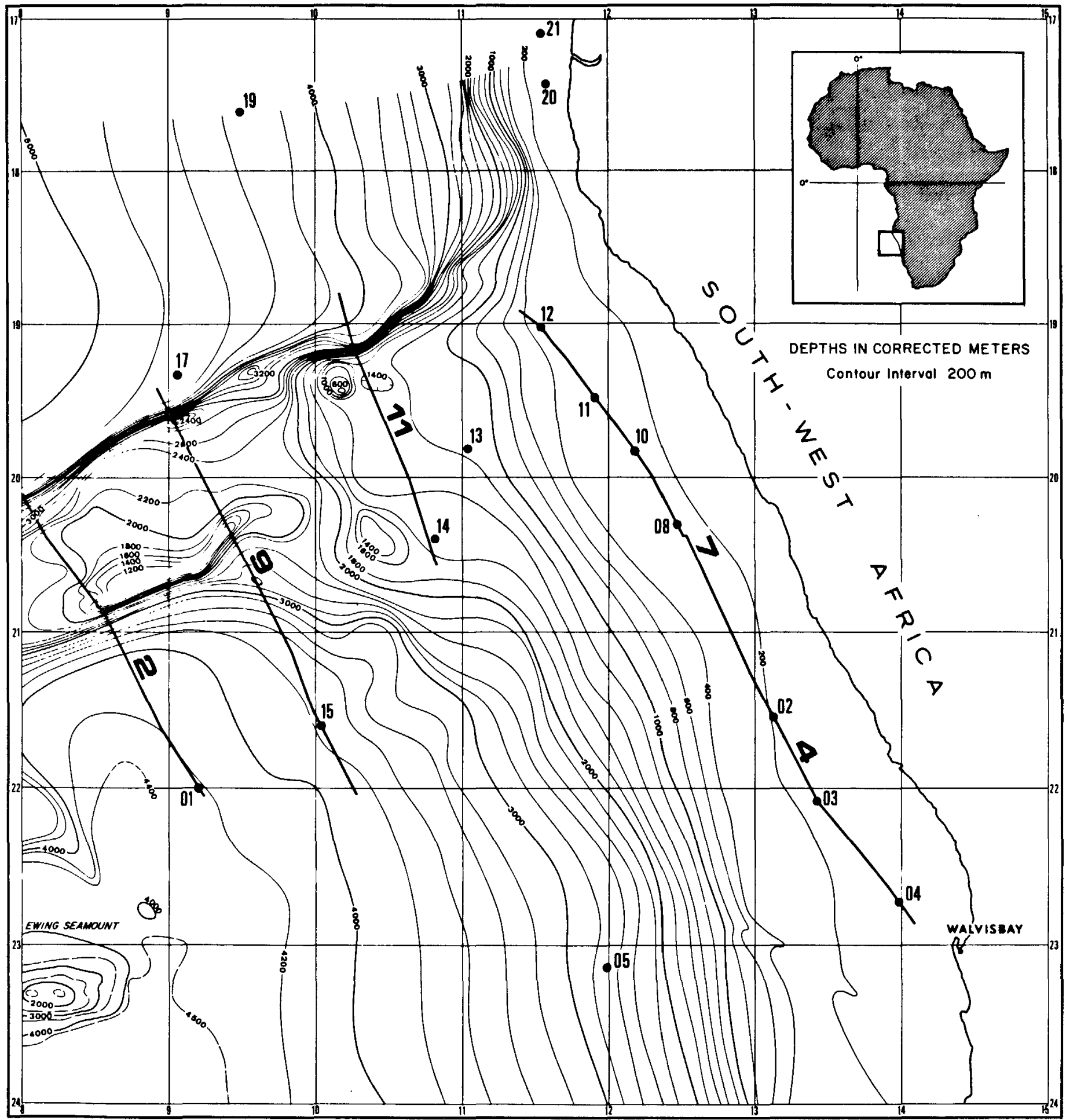

Figure 1. Bathymetry in corrected metres (Matthews, 1939). Heavy lines: continuous reflection profiles used in the paper. Circles: sonobuoy launching points.

1974). Table 1 lists the results of the corresponding sonobuoy refraction profiles.

\section{Relationship between Seismic Velocity and Depth}

The compressional wave velocity versus depth relationship for the sonobuoys recorded over the continental shelf of South
West Africa is shown in Figure 4, which also includes information derived from sonobuoy data from areas that cannot be considered typical of the shelf sedimentary structure. Buoy 4 was recorded over a basement high off Walvis Bay. This high also appears on the free-air anomaly map (Fig. 2) and on the seismic profiles of Du Plessis and others (1972). Buoy 12 was monitored over a sharp rise of all sedimen- tary horizons, probably in the area of the eastward continuation of the northern scarp of the Walvis Ridge (Figs. 2, 5). Buoys 13 and 14 were monitored over the complex region where the central basin of the Walvis Ridge meets the African margin.

The velocity-depth distribution on all other sonobuoys records obtained over the continental shelf is close to a linear relationship with very little deviation. The ve- 
GEOPHYSICAL STUDY OF THE EASTERNMOST WALVIS RIDGE, SOUTH ATLANTIC

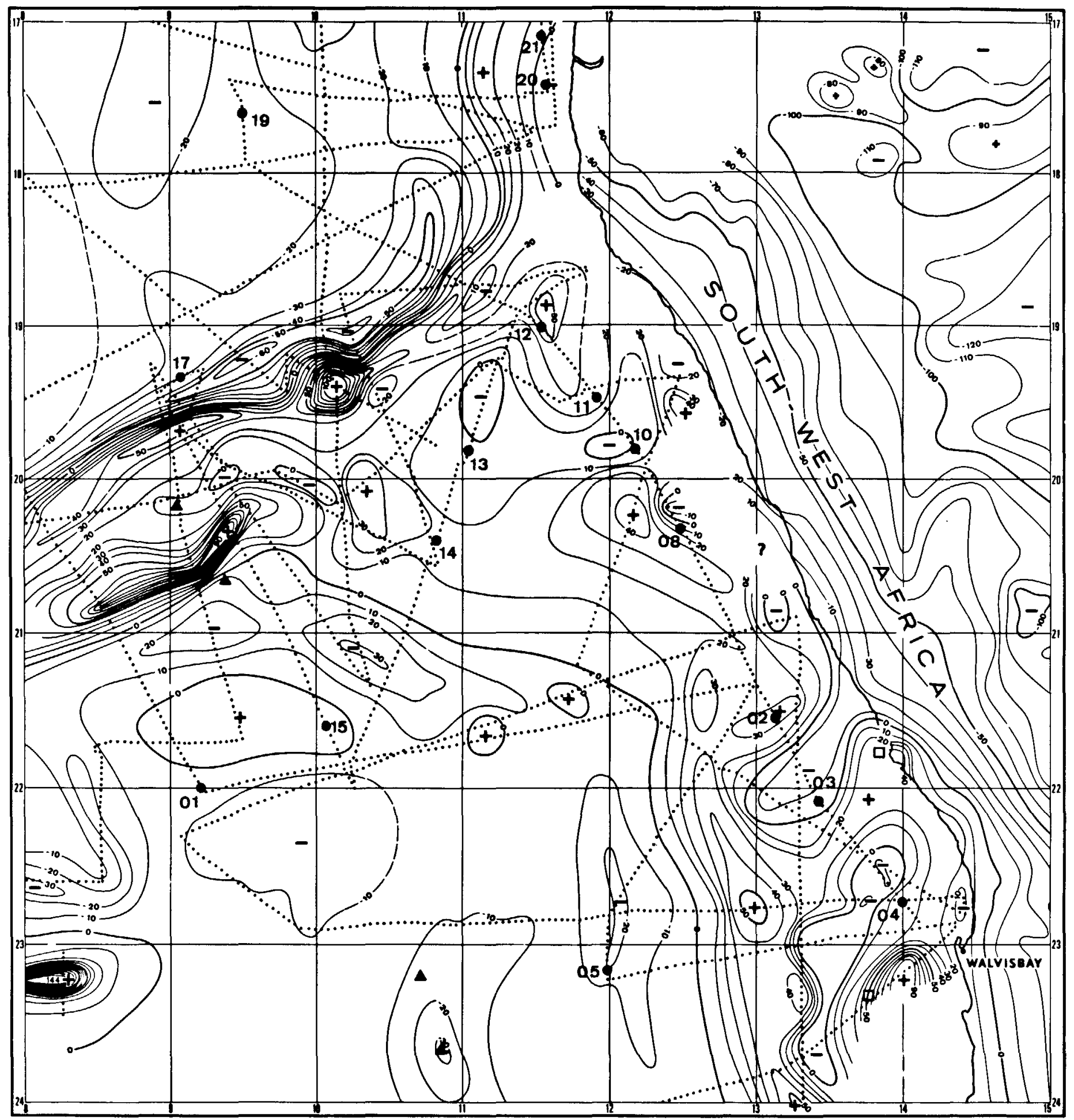

Figure 2. Gravity-anomaly map. Contour interval, 10 mgal. Free-air anomaly at sea and Bouguer anomaly on land (from the Geological Map of South West Africa [South Africa Geol. Survey, 1963]). Dotted lines, surface ships' gravity control; triangles, pendulum gravity stations (Worzel, 1965); squares, RV Akademik Kurtchatov measurements.

locity, ranging from 3.5 to $5 \mathrm{~km} / \mathrm{sec}$, shows a greater deviation, which we attribute to the slopes of the deeper interfaces; these are difficult to evaluate precisely on the reflection records (Fig. 5). The seismic velocities lower than $3.5 \mathrm{~km} / \mathrm{sec}$ seem to be mainly a function of the depth of the refractive horizons. This suggests that the increase in velocity with depth is mostly due to compaction. Although the mean velocity-depth law is linear, no curved refraction arrivals were detected. We conclude that the rectilinear refraction curves indicate the presence of horizons with noticeable velocity contrast, and we suggest that these horizons separate sedimentary layers of different natures or different depositional histories. These velocity contrasts would have been preserved through burial and compaction.
We have chosen, rather arbitrarily, to separate the velocities of the various horizons into five groups: (1) approximately 2.2 $\mathrm{km} / \mathrm{sec}(2.28 \mathrm{~km} / \mathrm{sec}$ [12], $2.24 \mathrm{~km} / \mathrm{sec}$ [11], $2.24 \mathrm{~km} / \mathrm{sec}[10], 2.13 \mathrm{~km} / \mathrm{sec}[8], 2.27$ $\mathrm{km} / \mathrm{sec}$ [2], and $2.28 \mathrm{~km} / \mathrm{sec}[3]$ ); (2) approximately $2.9 \mathrm{~km} / \mathrm{sec}(2.98 \mathrm{~km} / \mathrm{sec}[12]$, $3.0 \mathrm{~km} / \mathrm{sec}$ [10], $2.65 \mathrm{~km} / \mathrm{sec}$ [8], 3.09 $\mathrm{km} / \mathrm{sec}[2], 2.74 \mathrm{~km} / \mathrm{sec}$ [3]); (3) approximately $3.65 \mathrm{~km} / \mathrm{sec}(3.67 \mathrm{~km} / \mathrm{sec}[11], 3.68$ 


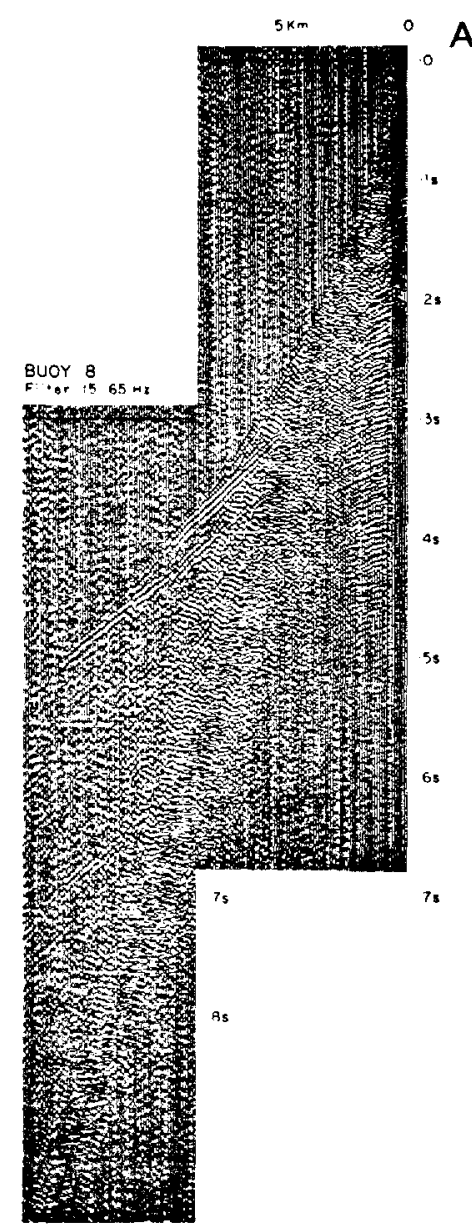

$\mathrm{km} / \mathrm{sec}$ [10], $3.48 \mathrm{~km} / \mathrm{sec}$ [8]); (4) approximately $4.35 \mathrm{~km} / \mathrm{sec}(4.15 \mathrm{~km} / \mathrm{sec}$ [11], 4.38 $\mathrm{km} / \mathrm{sec}[10], 4.21 \mathrm{~km} / \mathrm{sec}[8]) ;(5)$ approximately $5.50 \mathrm{~km} / \mathrm{sec}(5.57 \mathrm{~km} / \mathrm{sec}$ [12], 5.45 $\mathrm{km} / \mathrm{sec}$ [8], $5.46 \mathrm{~km} / \mathrm{sec}$ [3]). The fact that the seismic velocities can be grouped in such a way suggests that the sedimentary cover is fairly homogeneous over the whole continental shelf of South West Africa. The deviation of the compressional velocities around the five chosen mean values can be partly explained by the fact that the profiles were unreversed.

\section{Sedimentary Structure and History}

Two basement highs appear on the continental shelf, one in the prolongation of the northern flank of the Walvis Ridge near lat $19^{\circ} \mathrm{S}$ and the other off Walvis Bay near lat $23^{\circ} \mathrm{S}$ (the northern and southern parts of profiles 7 and 4, Fig. 5). These basement highs are marked by high-amplitude magnetic anomalies. Between these two basement highs, profiles 4 and 7 cut obliquely the isobaths between 100 and $300 \mathrm{~m}$ (Fig. 1). The profiles that were run perpendicularly to the margin during the Walda and Atlantis II-67 cruises show the presence of a thick prograding sedimentary cover, which appears between the two basement highs, on refraction profiles 2,8 , 10, and 11 (Fig. 6).
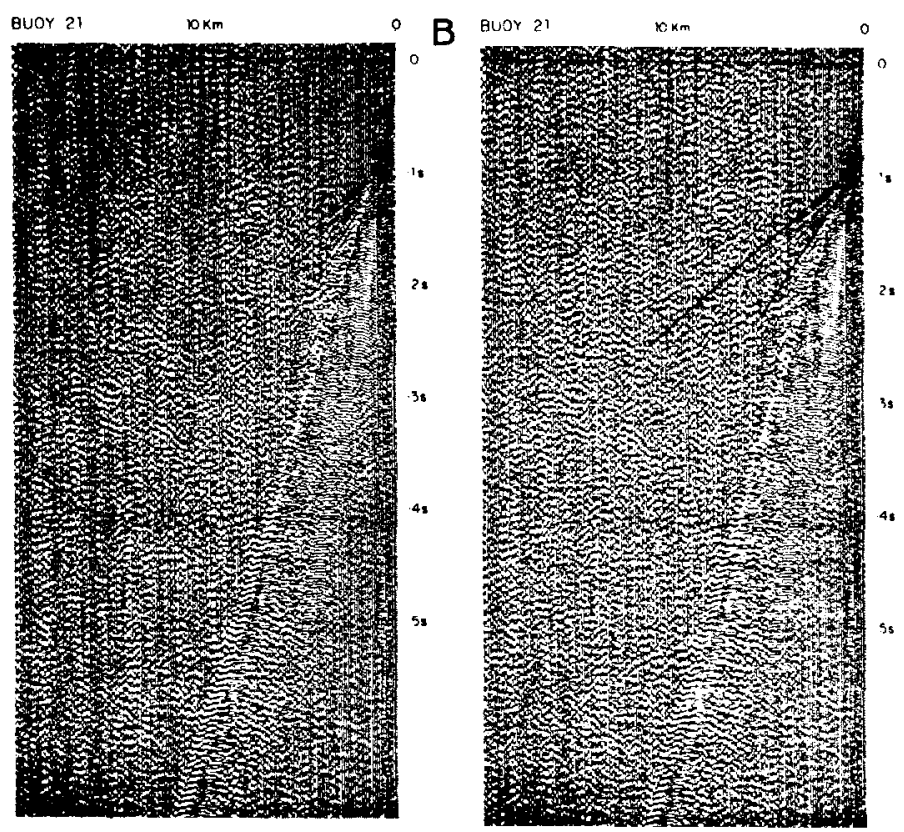

Figure 3. A, variable-area film record of sonobuoy 8, with interpreted film on right. $B$, variable-area film record of sonobuoy 21 , with interpreted film on right.
A representation of the depths of equalvelocity horizons is shown on Figure 6 (bottom); this gives an insight into the sedimentary history of the South West African shelf. The lines thus determined do not represent any real refractive horizons. In the central part of the profile, the equalvelocity lines are horizontal down to the 3.0 $\mathrm{km} / \mathrm{sec}$ line, a result that could have been foreseen with the help of Figure 4, in which the velocity-depth distribution for the upper horizons of sonobuoy records 11,10 , 8 , and 2 is markedly linear. Because compaction of sediments is a function of their age and depth (Faust, 1951), the horizontal- ity of sedimentary layers where compressional velocity is lower than $3.0 \mathrm{~km} / \mathrm{sec}$ suggests that there has been no uplift or subsidence since the deposition of the $3.0-\mathrm{km} / \mathrm{sec}$ layer. South of the northern flank of the Walvis Ridge, the bowl shape of the lines of equal velocity higher than 3.0 $\mathrm{km} / \mathrm{sec}$ indicates that this area subsided, assuming that the compaction limit is reached, or that the compressional velocity of the sediments is insensitive to compaction. If the compaction limit has not been reached, the deviation of the data rules out any hypothesis about vertical motion in this area.

TABLE 1. SEISMIC REFRACTION PROFILES ShOt IN THE AREA OF THE EASTERNMOST WALVIS RIDGe

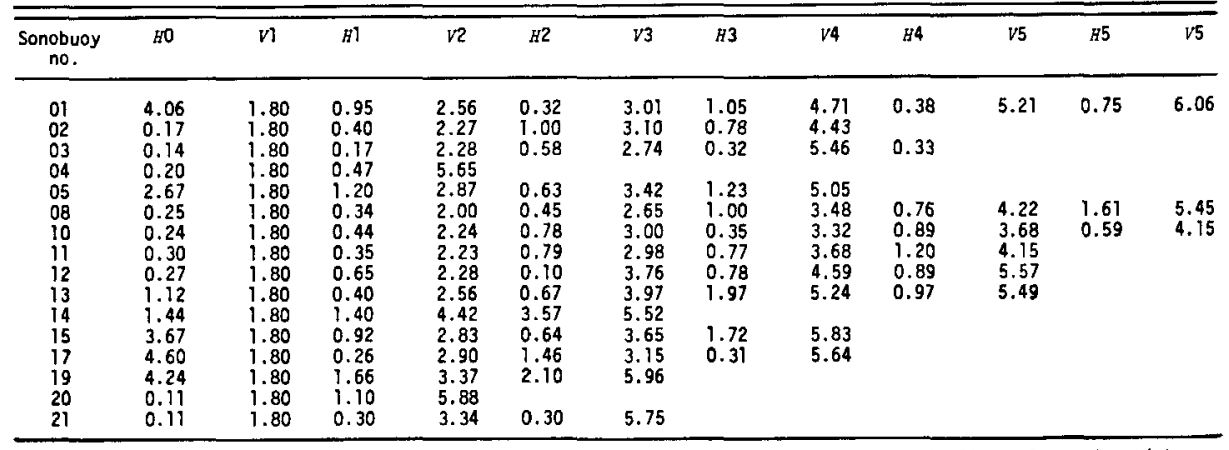

Note: Results obtained using expendable sonobuoys. Positfons of profiles are shown in Figure $1 . \quad H$ is thickness in $k+1$ lometres; $V$ ts compressional velocity in $k i l o m e t r e s$ per second of the varlous layers. Mean water velocity was set equal to $1.49 \mathrm{~km} / \mathrm{sec}$ (Mat thews, 1939). 
GEOPHYSICAL STUDY OF THE EASTERNMOST WALVIS RIDGE, SOUTH ATLANTIC

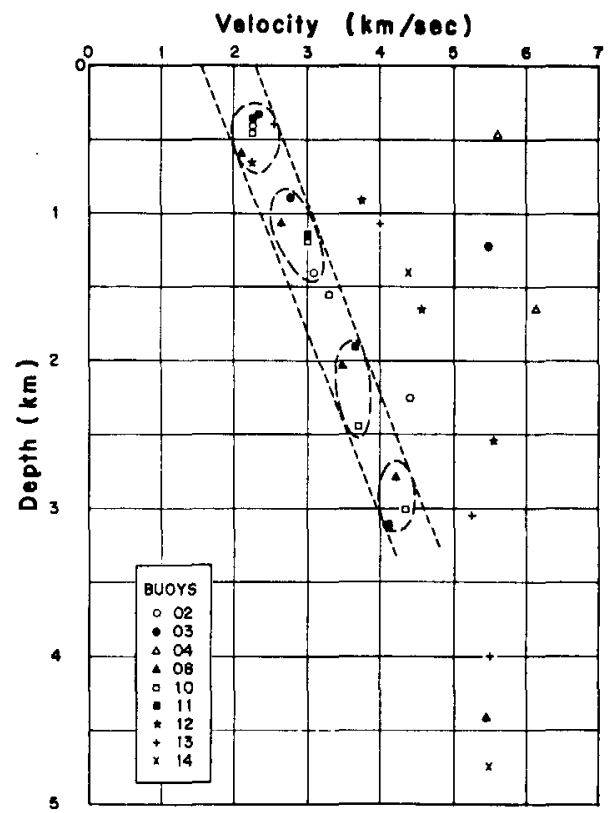

Figure 4. Velocity-depth plot of seismicrefraction profiles shot over continental margin of South West Africa from lat $19^{\circ} \mathrm{S}$ to $23^{\circ} \mathrm{S}$ (see text).

We suggest the following for the sedimentary history of the South West African continental shelf. Possible tectonic movements could have influenced the area in Late Cretaceous time, when the pole of opening of the South Atlantic migrated northward ( $75 \mathrm{~m} . \mathrm{y}$. B.P.). There is a suggestion that these movements occurred before or at the time of the deposition of the $3.5-\mathrm{km} / \mathrm{sec}$ layer (Fig. 6). Such a dating fits in with that of Bryan and Simpson (1971), who considered the $3.0-\mathrm{km} / \mathrm{sec}$ sediments to be of early Tertiary age. The sediment deposition would have then taken place in successive and distinct phases, thus creating velocity contrasts between different layers.

Two distinct areas of the continental shelf south of the Walvis Ridge stand out from the free-air anomaly map (Fig. 1). South of lat $21.5^{\circ} \mathrm{S}$ the anomalies are oriented southwest-northeast over the basement rise, which appears south of refraction profile 2 (Fig. 6). North of lat $21^{\circ} 5^{\prime} \mathrm{S}$ the anomalies roughly parallel the shelf and slope isobaths.

The high amplitude (a few hundred gammas) and small wave length (around 20 $\mathrm{km}$ ) magnetic anomalies are consistent with the rise of the basement layer to the southeast of sonobuoy 2 and to the northwest toward sonobuoy 12 (Fig. 6). The rapid flattening of the magnetic profile northwestward of buoy 2 and southeastward of buoy 12 indicates a steep descent of the magnetic basement layer.

Seismic-Refraction Study of the Prolongation of the Walvis Ridge

The surface expression and subsurface structure of the continental shelf north and

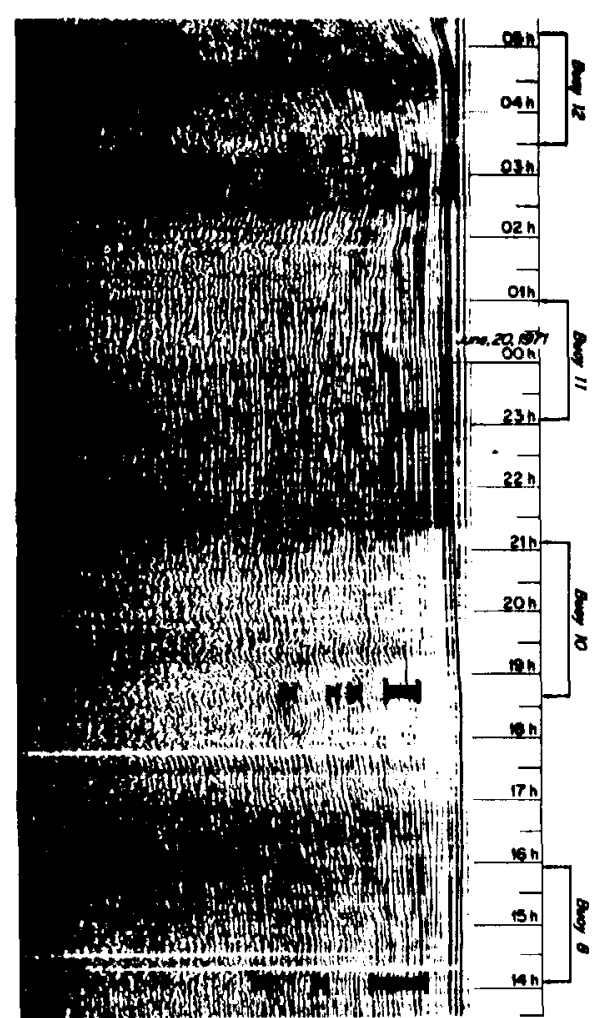

Figure 5. Variable-density record of seismicreflection profiles 4 and 7 (see location on Fig. 1). Ship's speed was about 6 knots; vertical exaggeration is about 15 to 20 . Depths of refracting horizons are shown at the vertical of the sonobuoys' launching points; velocity assumed for topmost layer varies from $1.7 \mathrm{~km} / \mathrm{sec}$ to 2.2 $\mathrm{km} / \mathrm{sec}$.

south of lat $18^{\circ} 30^{\prime} \mathrm{S}$, where the northern scarp of the Walvis Ridge meets the continental margin, are different. To the north, the shelf is narrow, and the sedimentary cover is thin; less than $0.5 \mathrm{sec}$ of sediment appears on sonobuoy profiles 20 and 21 (Table 1). The structure is also apparently simple - no sedimentary reflectors can be seen on the recording from sonobuoy 20 . Free-air gravity anomalies of medium amplitude closely follow the topography. To the south, the continental shelf is wide, and the shelf break is around $400 \mathrm{~m}$ (Goslin and others, 1974).

The continuation of the northern scarp of the Walvis Ridge can be followed under the continental shelf on seismic refraction and reflection records, as well as on magneticanomaly profiles (Figs. 5, 6). The continuation of the southern flank of the Walvis Ridge does not appear on seismicreflection and seismic-refraction records. However, two possibilities for the eastward continuation of the southern flank beneath the shelf stand out from the free-air anomaly contour map (Fig. 2): either toward the gravity high situated near lat $20^{\circ} 2^{\prime} \mathrm{S}$, long $12^{\circ} 2^{\prime} \mathrm{E}$ or toward the high situated near lat $18^{\circ} 8^{\prime} \mathrm{S}$, long $11^{\circ} 6^{\prime} \mathrm{E}$. In both cases, a northward associated gravity low would correspond to the eastward extension of the

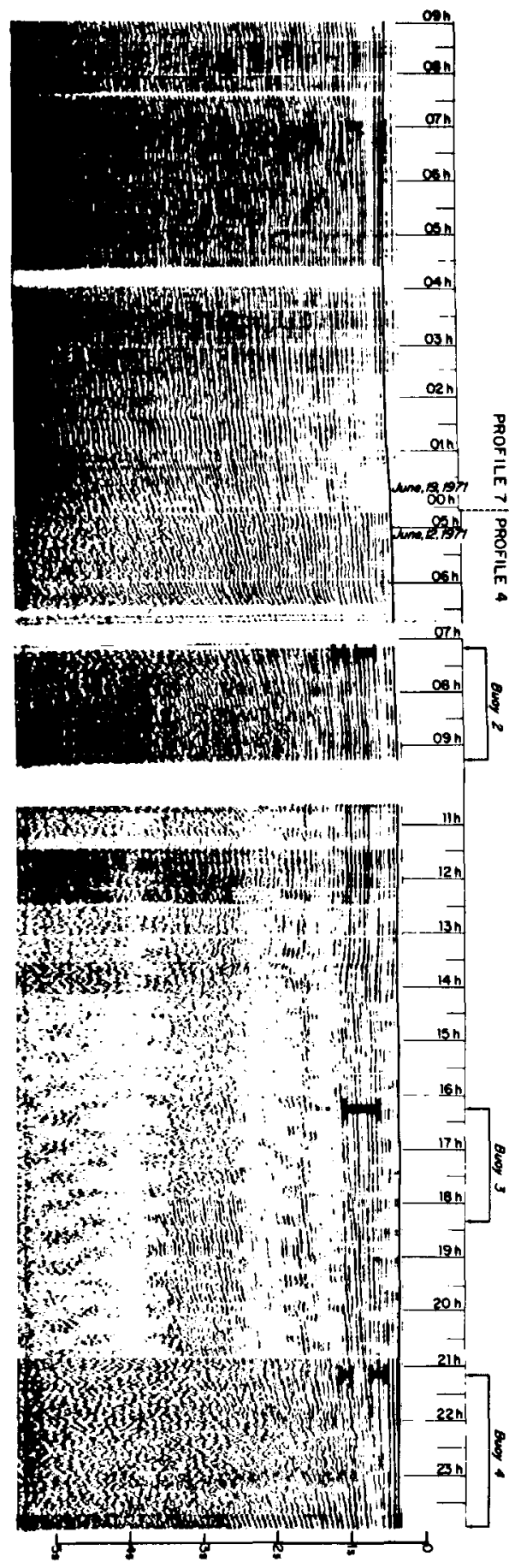

central basin of the ridge (Goslin and others, 1974). Nevertheless, the plot of the magnetic anomalies along the ships' tracks (Goslin and others, 1974, Fig. 5) allows us to rule out the first of the two possibilities mentioned above. Consequently, the southern crest of the Walvis Ridge seems to parallel the northern flank beneath the continental shelf.

\section{DEEP STRUCTURE OF THE EASTERNMOST WALVIS RIDGE}

Bathymetric and free-air gravity anomaly data (Figs. 1, 2) were presented and dis- 


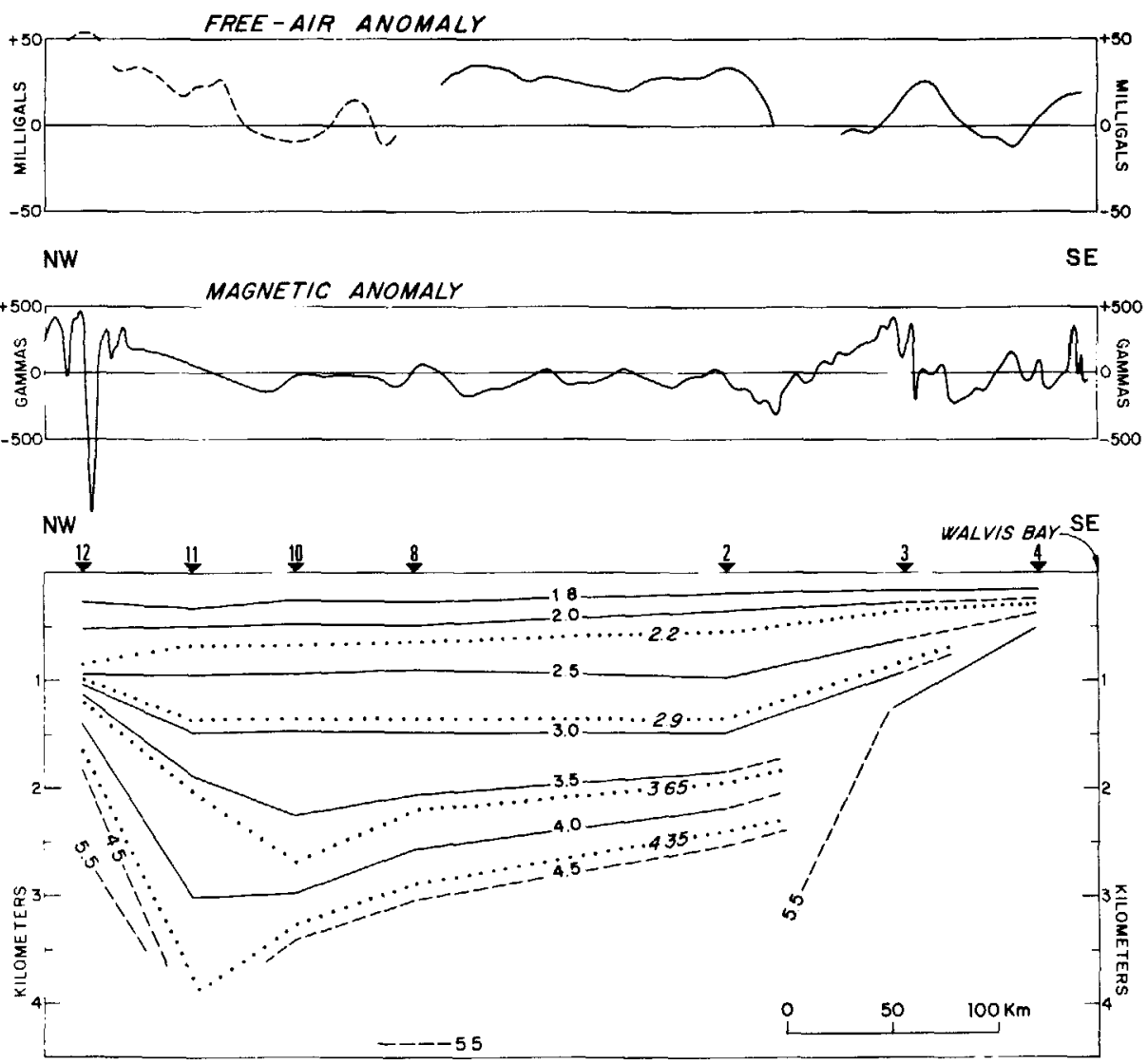

Figure 6. Crustal section through continental shelf of South West Africa from lat $19^{\circ} \mathrm{S}$ to $23^{\circ} \mathrm{S}$, as deduced from seismic-refraction profiles. Top and center: free-air and magnetic gravity-anomaly profiles. Dotted part of free-air anomaly profile is not considered reliable. Bottom, equal-velocity lines are drawn every $0.5 \mathrm{~km} / \mathrm{sec}$ from $2.0 \mathrm{~km} / \mathrm{sec}$ to $4.5 \mathrm{~km} / \mathrm{sec}$ and do not represent actual observed refracting horizons. Dotted lines represent mean velocities of probable refracting horizons.

cussed in an earlier paper (Goslin and others, 1974). They indicate that the easternmost segment of the Walvis Ridge has a cylindrical structure; this structure has been followed down to the acoustic basement on seismic-retlection records (Fig. 7).

Profiles 2, 9, and 11 (Fig. 1) will be used to investigate the deeper structure. These profiles have been projected on a line of constant azimuth $\left(330^{\circ}\right)$. The acoustic basement can be traced continuously along these three profiles (Fig. 7). We will thus be able to correct the observed free-air anomaly for the attraction of the sedimentary lavers and focus our interest on the deep layers situated below the acoustic basement.

\section{Basic Hypothesis for Gravity Models}

The gravity anomaly map (Fig. 2) and gravity profiles 2,9 , and 11 (Fig. 7) show that the free-air anomalies remain close to the zero level in the Angola and Cape Abyssal Plains, apart from local highs due to seamounts. These abyssal plains are therefore in general isostatic equilibrium.

The amplitude of the free-air anomalies is also quite small along the axial part of the Walvis Ridge (Fig. 2), in spite of the exis- tence of a thick sedimentary basin (Fig. 7). The width of the Walvis Ridge (as much as $200 \mathrm{~km}$ ) is great compared to the estimated isostatic compensation depth (about 30 $\mathrm{km})$. It thus seems probable that the Walvis Ridge is in local isostatic equilibrium over its entire extension (Bott, 1971). Furthermore, high-amplitude negative anomalies are found near the base of the flanks of the ridge. They reach $-60 \mathrm{mgal}$ and $-30 \mathrm{mgal}$ in the Angola and Cape Basins, respectively. These negative anomalies do not seem to coincide with any thick sedimentary basins in these regions and could therefore be the result of an edge effect due to a deep compensating mass below the Walvis Ridge.

Two-dimensional Bouguer anomalies were computed along profiles 2,9 , and 11 , assuming a crustal density of $2.7 \mathrm{~g} / \mathrm{cm}^{3}$. The bowl shape of the calculated anomaly (Fig. 8) suggests that the Walvis Ridge is compensated by rather deep-seated masses (Bott, 1971). A very simple model is tested along profile 2 in order to confirm such a hypothesis (Fig. 8). The compensating mass is arbitrarily taken to consist of a rectangular prism below the Walvis Ridge with a density chosen to be $3.0 \mathrm{~g} / \mathrm{cm}^{3}\left(-0.4 \mathrm{~g} / \mathrm{cm}^{3}\right.$ density contrast with the adjacent upper mantle). A cylindrical body with a 2.7 - $\mathrm{g} / \mathrm{cm}^{3}$ density, emplaced in the Angola Basin, accounts for the difference between the depth of this basin and the Cape Basin. The fit between the observed anomaly and the anomaly computed for this very simple model is quite good (Fig. 8).

Free-air and Bouguer anomaly observations indicate with some precision the extent to which a structure is isostatically compensated; however, they do not allow us to choose between the different hypotheses of compensation. As far as we know, no long refraction profiles have yet been shot in the Walvis Ridge area. Consequently, the only way to choose between compensation hypotheses and to infer the approximate shape and density of layers situated below the acoustic basement is gravity modeling. We assume, for each model, that the Walvis Ridge is everywhere in local isostatic equilibrium; that is, the weight of any column of unit surface is set equal at any point of the structure.

\section{Construction of Models}

The basic hypothesis of all the models local isostatic equilibrium everywhere has an important consequence. Slight variations of the chosen densities or of the topography of the layers will only change the mass distribution of each vertical section. The resulting changes in the computed anomaly will remain smaller than those caused by shallow sources and will not help much in choosing among different models. Such a choice will be possible only between models that differ radically, such as the following:

1. Models in which the crustal structure under the Walvis Ridge differs from a typical oceanic crustal structure. This would be a consequence, for example, of the presence of a mass of material lighter than layer 3 under the ridge, such as a body of serpentinite or serpentinized peridotite. The isostatic compensation would then be mostly of the Pratt type.

2. Models in which the distribution of the densities is similar to the typical oceanic crust. In this case, however, the nature of the layers under the Walvis Ridge could differ notably from that of the ones composing the oceanic crust, even though they have the same densities.

\section{Test of Models}

Densities are assigned to the sediment layers from seismic velocities, making use of the Nafe and Drake curve (Talwani and others, 1959). A density of $2.65{\mathrm{~g} / \mathrm{cm}^{3}}^{3}$ taken for layer 2 (Nafe and Drake in Talwani and others, 1959) and of $2.95 \mathrm{~g} / \mathrm{cm}^{3}$ for layer 3 (for example, Le Pichon, 1969; Goslin and others, 1972). Models were extended to great distances in both directions in order to avoid edge effects, and the computation was carried out with a two- 


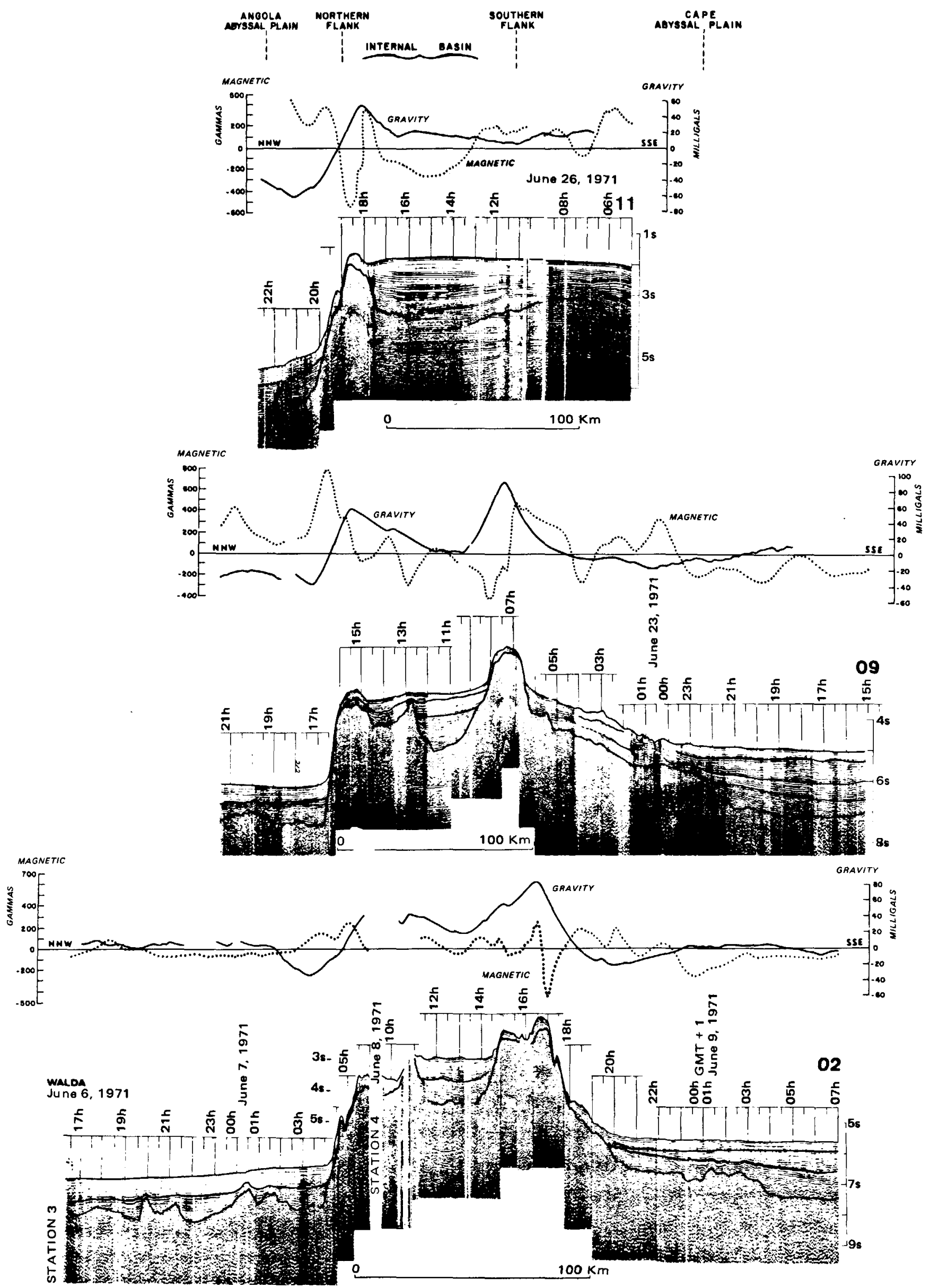

Figure 7. Interpreted seismic-reflection profiles 2,9 , and 11 across Walvis Ridge with free-air gravity and magnetic anomalies. Lowest reflector corresponds to top of layer 2. 


\section{GOSLIN AND SBUET}

dimensional approximation (Talwani and Heirtzler, 1964).

All models have been tested against observed profiles 2,9 , and 11 (Fig. 1). In the following discussion, emphasis will be on profile 9 , which is located in a central position and close enough to seismic-refraction profiles 13,14 , and 15 (Table 1 )

\section{Models with a Low-Density}

Body under the Walvis Ridge

The computed two-dimensional Bouguer anomaly (Fig. 8) seems to favor compensation by deep-seated bodies of small density contrast. We nevertheless tested some models in which the compensation is due to a shallow body of very light material and in which isostatic compensation is achieved according to Pratt's hypothesis. F. Vine (1973, personal commun.) suggested a model in which the compensating mass is serpentinite or serpentinized peridotite, frequently recovered by dredging in fracture zone areas (Bonatti, 1968). If the density chosen for serpentinite is $2.4 \mathrm{~g} / \mathrm{cm}^{3}$ (F. Vine, 1973 , personal commun.), that is, at the lower end of the density range for serpentinite (Hatherton, 1967), the computed attraction does not fit the observed anomaly highs and produces no significant edge effect on either side of the Walvis Ridge.

\section{Models with Variable Thickness of the} Crustal Layers

1. Models in which layer 2 is of constant thickness. The fit between the observed and computed gravity anomaly is good along most of the length of the profiles when the thickness of layer 2 is taken to be $1 \mathrm{~km}$, which is in the range of thicknesses generally proposed for oceanic layer 2 (Bott and others, 1971; Goslin and others, 1972; Bottinga, 1973). In this case, the $2.95-\mathrm{g} / \mathrm{cm}^{3}$ density root reaches depths around $28 \mathrm{~km}$ under the Walvis Ridge on profiles 2 and 9.

2. Models in which the ratio between the thicknesses of layers 2 and 3 is kept constant. In this type of model, the deep structure of the Walvis Ridge results from a thickening of layers 2 and 3 , the ratio between thicknesses remaining constant and equal to 0.25 , which is typical for oceanic crust (Le Pichon, 1969; Bottinga, 1973). The computed attraction fits well with the observed free-air anomaly along the profiles; discrepancies are smaller than 10 mgal. The base of layer 3 reaches a depth of $25 \mathrm{~km}$ under the ridge in this model. The at traction due to this model is not strikingly different from the one due to the model where the thickness of layer 2 is kept constant.

3. Models with smoothed interfaces. Local isostatic equilibrium is achieved in the two models discussed above, in Airy's hypothesis, by variation of the thickness of layers 2 and 3. This hypothesis produces jagged and unrealistic shapes for the deep interfaces. Models were consequently constructed with smoothed interfaces (Figs. 9, $10)$. In this case, the isostatic equilibrium becomes "regional" at a scale of a few tens of kilometres instead of "local," the departures from local equilibrium causing only small local attraction (less than $5 \mathrm{mgal}$ ). The depth reached by the light root is comparable to that of constant-ratio models.

\section{Interpretation of the Models}

The shape of the Bouguer anomaly and the attraction computed for a simple model (Fig. 8) suggest that the Walvis Ridge is compensated at a depth of 25 to $30 \mathrm{~km}$. The computed Bouguer anomaly is not very sensitive to the shape of the deep compensating body. The attraction caused by a double-rooted prism also fit the observed anomaly.

The models of the three profiles, spaced over the eastern segment of the Walvis Ridge and locally in equilibrium, confirm the compensation of the Walvis Ridge by a light root reaching depths of around $25 \mathrm{~km}$, whereas the Moho in adjacent basins reaches depths of 10 to $15 \mathrm{~km}$. The shape of the root is quite similar in all three profiles (Fig. 10).

The lack of deep refraction lines in the area studied does not allow us to exclude the possibility that the light root is made up of some abnormal layer 3. Palmason (1971) suggested the existence of an unusually thick layer 3 of high density $\left(3.00 \mathrm{~g} / \mathrm{cm}^{3}\right)$ under Iceland. Bowin (1973) proposed a similar structure under the Ninetyeast Ridge. Unfortunately, no data are available in the Walvis Ridge area to determine the nature and chemical composition of such a root. The composition of layer 3 under the ridge could be different from that of the typical oceanic layer created at mid-oceanic

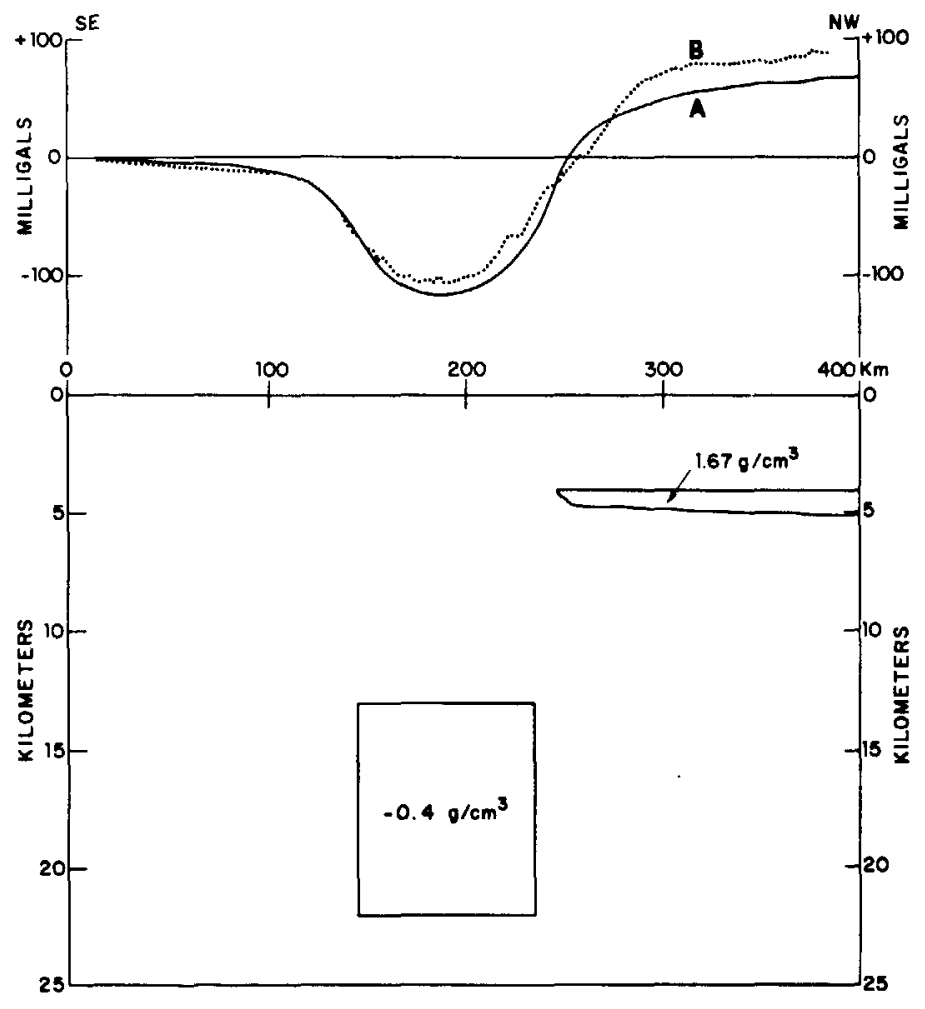

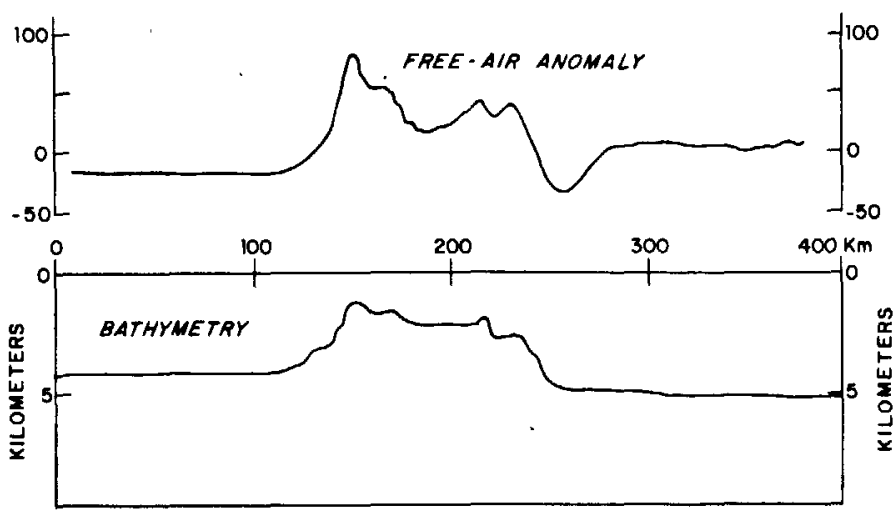

Figure 8. Left part of figure shows simplest isostatic compensation hypothesis with a low-density body $\left(3.0 \mathrm{~g} / \mathrm{cm}^{3}\right)$ under the Walvis Ridge between depths of 13 and $22 \mathrm{~km}$. Right part of figure shows bathymetric profile and free-air gravity-anomaly profile. A $2.7-\mathrm{g} / \mathrm{cm}^{3}$-dense body is introduced at the northwestern end of profile 2 in order to account for difference of water depth between Angola and Cape Basins. Continuous line A shows computed attraction of model; dotted line B shows two-dimensional Bouguer anomaly computed with density of $2.7 \mathrm{~g} / \mathrm{cm}^{3}$ for filling material. 


\section{GEOPHYSICAL STUDY OF THE EASTERNMOST WALVIS RIDGE, SOUTH ATLANTIC}

ridge axes. Abnormal mechanisms that could be due to a mantle hot spot now situated under Iceland (Morgan, 1971, 1972a, 1972b) were proposed by Bott and others (1971) to explain the structure and formation of the Iceland-Faeroes Ridge.

Two free-air anomaly profiles (Dehlinger, 1969; Lucas, 1971) recorded over the Hawaiian chain are shown in Figure 10 for comparison with those recorded over the Walvis Ridge. The free-air anomaly shows a high-amplitude peak $(150 \mathrm{mgal})$ over the Hawaiian chain and no minimum over the center of the structure (Vening Meinesz, 1941; Gunn, 1943). A negative anomaly of large wave length (several hundred kilometres) is present at the base of the chain and is followed seaward by a weak positive anomaly (Dehlinger, 1969; Lucas, 1971; Watts and Cochran, 1974). It seems that the mass of the Hawaii-Emperor chain, which was superimposed over a cold and rigid lithosphere, caused a depression of this lithosphere on both sides of the chain and an upward flexure seaward of this depression (Vening Meinesz, 1941; Gunn, 1943; Walcott, 1969; Lucas, 1971; Watts and Cochran, 1974). Along profiles over the Walvis Ridge (Fig. 11), on the other hand, the free-air anomaly returns to a low amplitude (less than $15 \mathrm{mgal}$ ) as near as 50 $\mathrm{km}$ away from the ridge. Consequently, the Walvis Ridge does not appear to be a load superimposed over the lithosphere. Because the Walvis Ridge is locally in isostatic equilibrium, it seems to have been created, together with its compensating root of light material, contemporaneously with the adjacent lithosphere. The presence of middle Cretaceous sediments, dredged on the top of the Walvis Ridge (Pastouret and Goslin, 1974), favors a progressive creation of the ridge together with the opening of the South Atlantic Ocean. Moreover, the total subsidence of the ridge $(2.5 \mathrm{~km})$ was similar to the subsidence of adjacent basins (Pastouret and Goslin, 1974; Sclater and Detrick, 1973). This suggests that no decoupling existed between the ridge and the adjacent lithosphere and that isostatic equilibrium was probably preserved since the formation of the Walvis Ridge.

\section{EVOLUTION OF THE WALVIS RIDGE}

Aseismic ridges are of great interest as possible guides for tracing plate motions back in time (Morgan, 1972b; Wilson, 1973). The two major aseismic ridges of the South Atlantic, the Rio Grande Rise and the Walvis Ridge, are particularly well suited to investigation because, for example, the original fit between South America and Africa is well controlled. Any hypothesis on the opening of the South Atlantic must take account of the two ridges both relative to their origin and to the geometric constraints that they enforce on the kinematics of the

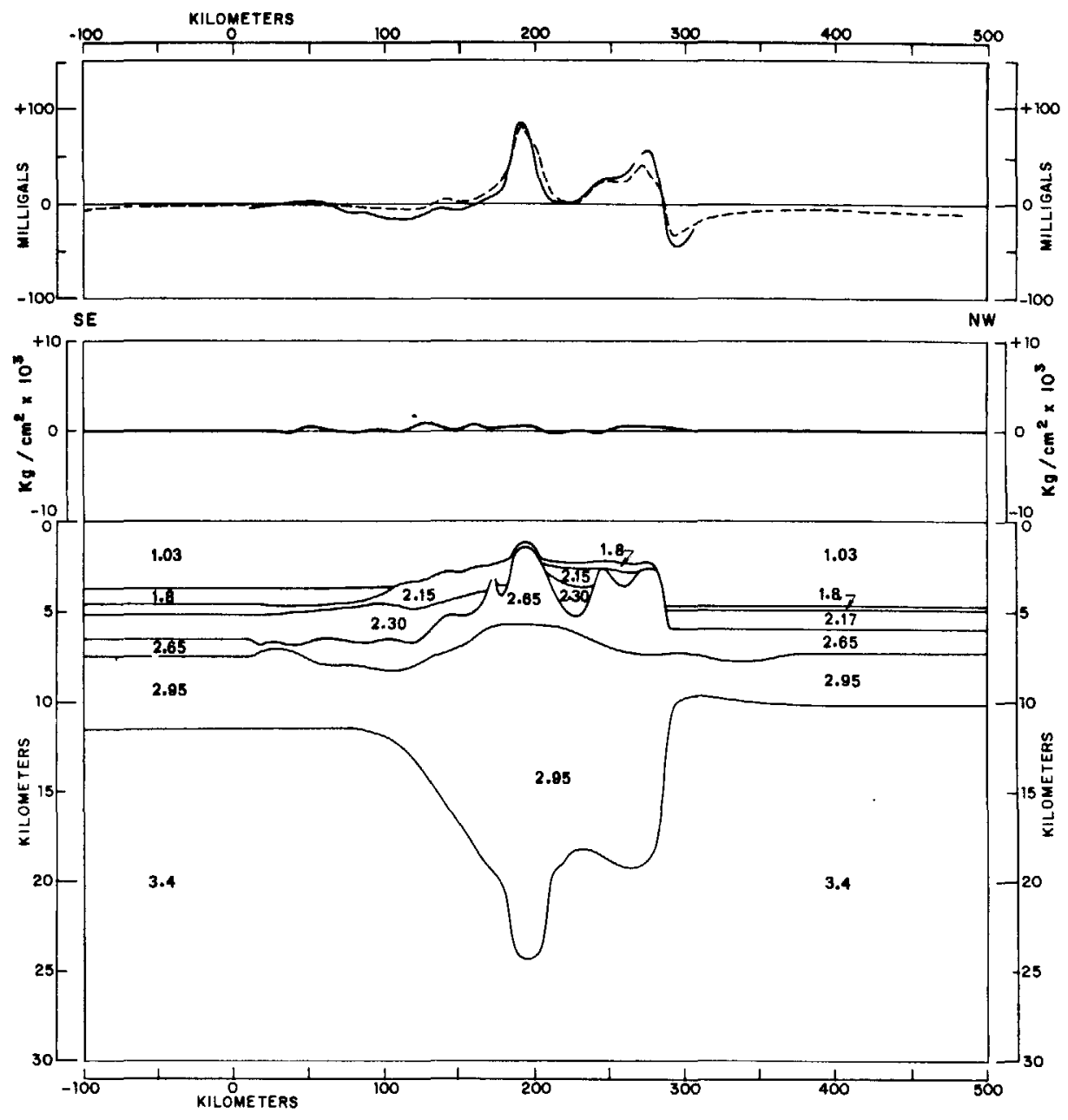

Figure 9. Gravity model of the Walvis Ridge along profile 9. Continuous line, observed free-air anomaly. Dotted line, computed attraction. Interfaces between layers 2 and 3 and layers 3 and 4 were smoothed visually. Middle curve of figure indicates variations of weight of $10-\mathrm{km}$-spaced columns from weight of a standard column of oceanic crust.

opening itself. We review here various hypotheses that have been proposed, and we outline a model based on the present study which incorporates evidence from previous studies.

\section{Review of Previous Hypotheses}

\section{Uplift Hypothesis}

Ewing and others (1966) argued that the Walvis Ridge and the Rio Grande Rise may have been emplaced by an uplift of the oceanic crust quite a long time after formation of the crust. Pliocene vertical motions of great amplitude would have occurred along Eocene lines of weakness in the oceanic crust, and the movements would not have been accompanied by widespread volcanism. Dickson and others (1968) revived the uplift hypothesis within the framework of a nonpermanent Atlantic Ocean. According to them, the uplift would have occurred between 75 and 50 m.y. B.P., relieving the stresses that had been built up during a previous period of slow spreading.

The formation of the aseismic ridges in the South Atlantic during a Cenozoic tectonic phase as inferred by Ewing and others (1966) can be rejected in light of recent data on micropaleontology, sedimentology, and gravity. The analysis of fossils dredged on the northern scarp of the Walvis Ridge dates the central part of the easternmost segment as being Albian-Cenomanian (about 100 m.y. B.P.; Pastouret and Goslin, 1974). These authors also suggested that the Walvis Ridge may have undergone a large-amplitude subsidence from its position of formation in shallow water. Results of deep-sea drilling led Maxwell and others $(1970 \mathrm{a}, 1970 \mathrm{~b})$ to a similar conclusion for the Rio Grande Rise. Conclusions drawn from gravity data presented in this paper also favor formation of the Walvis Ridge over a nonrigid and therefore young oceanic lithosphere, rather than by uplift of older oceanic crust.

According to Le Pichon (1968), Francheteau (1970), Le Pichon and Hayes (1971), and Francheteau and Le Pichon

\section{Transform Fault Hypothesis}



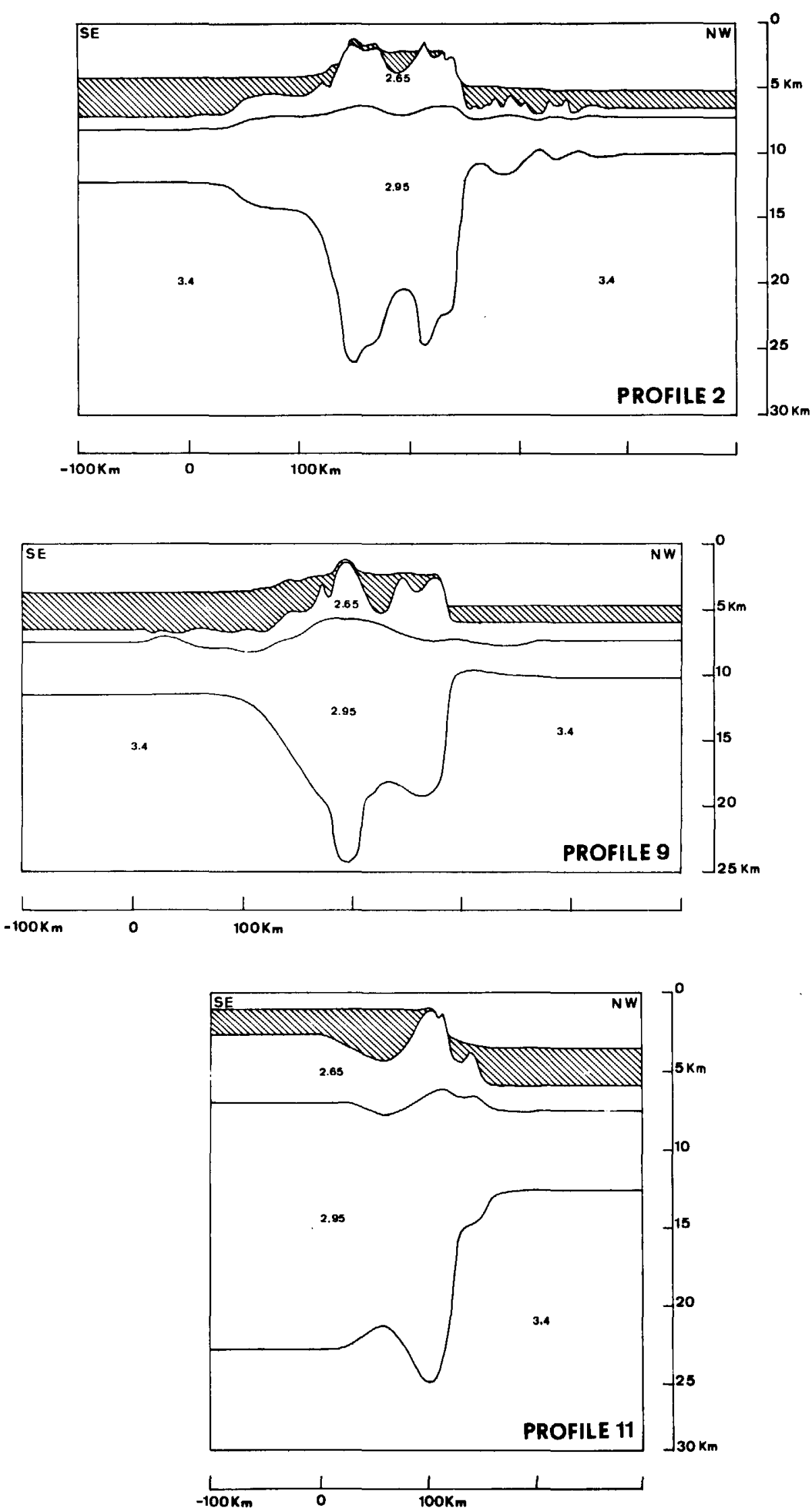

Figure 10. Models of deep structure of the Walvis Ridge along profiles 2, 9, and 11 after smoothing of the deep interfaces. Hachured areas represent sedimentary cover. Respective densities of layers 2,3 , and 4 are $2.65 \mathrm{~g} / \mathrm{cm}^{3}, 2.95 \mathrm{~g} / \mathrm{cm}^{3}$, and $3.4 \mathrm{~g} / \mathrm{cm}^{3}$. Northern scarp of Walvis Ridge is on right-hand side of figure.
(1972), transform faults played an important role in the creation of the oldest parts of the Walvis Ridge and the Rio Grande Rise. The good fit berween the trends of these parts and the small circles relative to the initial pole of opening proposed by these authors lend support to such a hypothesis. Recent data on the easternmost Walvis Ridge (Goslin and others, 1974) and on the gulf of Guinea (Mascle and Sibuet, 1974) confirm the fit.

According to Le Pichon (1968) and Francheteau (1970), the Walvis Ridge and Rio Grande Rise were probably present since the beginning of the opening of the South Atlantic in Early Cretaceous time (135 to 125 m.y. B.P., after Amaral and others, 1966, and Siedner and Miller, 1968). Release of time stresses after the migration of the pole of opening in Late Cretaceous time created the north-south-oriented segments of the Walvis Ridge and Rio Grande Rise (Le Pichon and Hayes, 1971; Francheteau and Le Pichon, 1972).

The following peculiar features of the Walvis Ridge remain unexplained by the tranform fault hypothesis: (1) No offset is found either in the coast lines or in the shallow isobaths where the Walvis Ridge meets the African continental margin. This was noted by Francheteau and Le Pichon (1972) as a major drawback to their hypothesis. (2) The western segment of the Walvis Ridge does not fit along a small circle around the present pole of opening (lat $67^{\circ} 3^{\prime} \mathrm{N}$, long $\left.39^{\circ} 5^{\prime} \mathrm{W}\right)$ inferred by Le Pichon and Hayes (1971). However, lack of bathymetric data on the westernmost segment of the Walvis Ridge does not allow us to exclude the possibility of an en echelon structure for this segment. A segment with an en echelon structure should then mark the termination of the Rio Grande Rise; however, on the basis of bathymetric data (Uchupi, 1971), this does not seem to be the case.

\section{Hot-Spot Hypothesis}

Morgan (1972a) supposed that the hot spots formed a rigid frame of reference from which plate motions could be studied, but this point has been much debated (for example, Burke and others, 1973; Molnar and Atwater, 1973; Le Pichon and others, 1973). Wilson (1965), Dietz and Holden (1970), Morgan (1971, 1972a, 1972b), and Ladd and others (1973) have suggested that the presence of a mantle hot spot would explain the origin of the Walvis Ridge and Rio Grande Rise. According to Morgan (1972b), six Atlantic hot spots would have rifted the American and African plates apart and created the Atlantic Ocean; continental volcanism, occurring prior to the opening of the Atlantic and caused by these hot spots, can be found on both continents (Kaoko volcanic rocks in Africa - Siedner and Miller, 1968; Sera Geral basalt in 
GEOPHYSICAL STUDY OF THE EASTERNMOST WALVIS RIDGE, SOUTH ATLANTIC

South America - Amaral and others, 1966). The motion of the African plate over the mantle would have had a northeastward direction during Cretaceous time. A sinistral rotation would have accompanied this motion until the closure of the Tethys Sea in early Cenozoic time $(65$ m.y. B.P.; Dietz and Holden, 1970).

\section{Proposed Hypothesis}

Gravity data for the easternmost Walvis Ridge, presented above, show that the ridge is compensated at depth by a body with a density of almost $2.95 \mathrm{~g} / \mathrm{cm}^{3}$. We have suggested that this body probably represents a thick, abnormally dense layer 3. Palmason (1971) measured the presence of a $10-\mathrm{km}$-thick layer 3 under Iceland, that is, about twice the thickness of the typical oceanic layer; the density, deduced from seismic-refraction profiles, is $3.0 \mathrm{~g} / \mathrm{cm}^{3}$. Bott and others (1971) suggested that a 15 - to $20-\mathrm{km}$-thick layer with a density of 2.90 $\mathrm{g} / \mathrm{cm}^{3}$ lies under the Iceland-Faeroes Ridge. Lastly, Bowin (1973) inferred a density of $3.05 \mathrm{~g} / \mathrm{cm}^{3}$ for a $25-\mathrm{km}$-deep "root" under the Ninetyeast Ridge. The existence of a thick layer with a density close to $3.0 \mathrm{~g} / \mathrm{cm}^{3}$ thus seems a feature common to several aseismic ridges. The formation of this layer could be the result of a rise of deep material from abnormal regions of the mantle accompanied by peculiar magmatic processes, which account for the creation of structures with large relief such as the Walvis Ridge (W. J. Morgan, 1973, personal commun.).

The results of geochemical analyses of basalt dredged on the northern scarp of the Walvis Ridge (Hekinian, 1972; H. Bougault, 1974, oral commun.) show that this basalt has a different rare-earth composition than both mid-oceanic-ridge basalt and "island-type" basalt. The rareearth distribution of the Walvis Ridge basalt is, on the other hand, close to that of other aseismic ridges (Ninetyeast Ridge, Cocos Ridge, Iceland-Faeroes Ridge) that are believed by some authors to have been created by hot spots and mantle plumes (Bowin, 1973; Hekinian, 1975).

The creation of the Walvis Ridge by a mantle hot spot and plume provides an appealing explanation for the peculiar petrology of the basalt, the deep structure of the easternmost segment as deduced from gravity results, and the large relief of the ridge. The mantle hot spot has had noticeable effects on land when rifting began in the South Atlantic (Kaoko and Seral Geral volcanism, for example). The mid-oceanic ridge was situated over the plume throughout the initial phase of opening (Burke and Wilson, 1972; Wilson, 1973). The older segments, oriented roughly east-west, were created during this first phase (before 75 m.y. B.P.). The hot spot has remained under the African plate since early Cenozoic time. This location of the hot spot is responsible
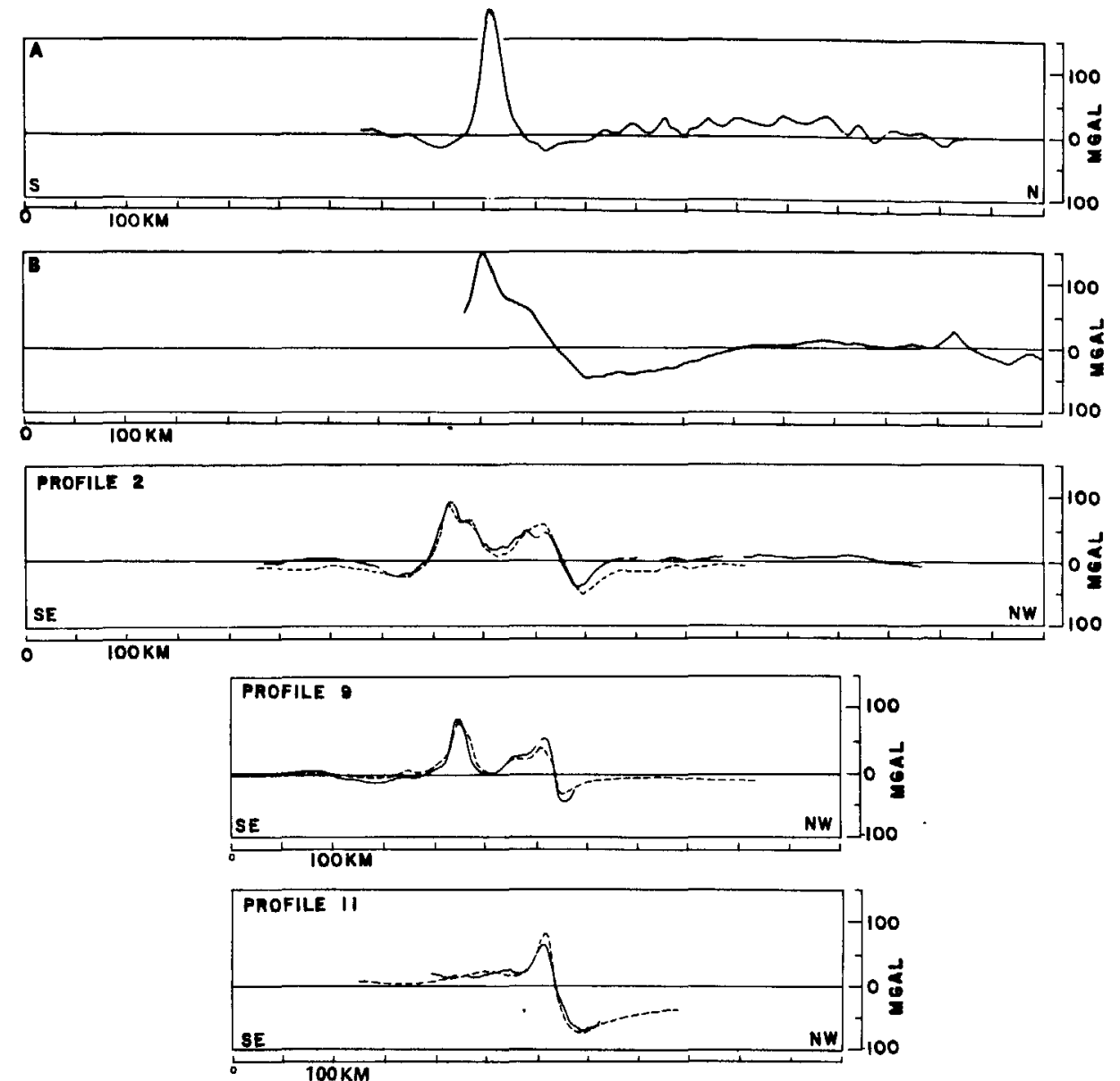

Figure 11. Observed free-air anomaly along profiles 2,9 , and 11 (continuous lines) and computed attractions caused by models of Figure 10 (dotted lines). Free-air anomaly profiles over the Hawaiian seamount chain (A, Dehlinger, 1969; B, Lucas, 1971) are shown for comparison.

for the absence of any recently created segment extending from the Rio Grande Rise to the Mid-Atlantic Ridge on the South American plate (W. J. Morgan, 1973, personal commun.).

The coincidence of the trends of the northern scarp of the Walvis Ridge and of the small circles centered about the initial pole of opening for the South Atlantic (Le Pichon and Hayes, 1971; Mascle and Sibuet, 1974) implies that the direction of relarive motion between the African and South American plates and the motion of these same plates over the mantle were identical throughout the first phase of opening. Such a coincidence between the directions would be more probable if the hot spots had initiated the rifting in the South Atlantic, as proposed by Morgan (1972b). The great change in direction of motion of the African plate over the mantle, as indicated by the presence of three main $W$ alvis Ridge segments of different strike, is difficult to believe, especially if the hot spots provide the energy for plate motion (Morgan 1972b).

The following mechanism is proposed to account for the en echelon structure of the Walvis Ridge (X. Le Pichon, 1973, oral commun.): the horizontal dimensions of the mantle plume are fairly large (more than $150 \mathrm{~km}$ in diameter, according to Morgan [1972a]), and magma rising from the manthe extrudes through the most convenient zone of weakness. As the plate motion continues, this zone of weakness goes away from the plume until it is too far away from its center for extrusion to continue through it. Some magma then issues from the next zone of weakness, eventually creating a transverse segment. The geometric and physical parameters of the mantle hot spot bear directly on the dimensions of the successive segments that are formed by such a process.

\section{ACKNOWLEDGMENTS}

We gratefully acknowledge the help of scientists and crew aboard the R/V Jean Charcot. J. Bonnin wrote the computer programs for projecting geophysical data on a given azimuth. Discussions with J. Francheteau, X. Le Pichon, W. J. Morgan, and F. Vine were very useful. C. O. Bowin, H. Hoskins, X. Le Pichon, J. Mascle, and H. D. Needham critically reviewed the manuscript and made helpful suggestions. We thank D. Carré, N. Guillo, and Y. Potard for assistance. 


\section{GOSLIN AND SIBUET}

\section{REFERENCES CITED}

Amaral, G., Cordani, U. G., Kawashita, K., and Reynolds, J. H., 1966, Potassium argon dates on basaltic rocks from southern Brazil: Geochim. et Cosmochim. Acta, v. 30, p. $159-189$.

Bonatti, E., 1968, Ultramafic rocks from the Mid-Atlantic Ridge: Nature, v. 219, p. 363-364.

Bort, M.H.P., 1971, The interior of the Earth: London, Edward Arnold Pubs., 316 p.

Bott, M.H.P., Browitt, C.W.A., and Stacey, A. P., 1971, The deep structure of the IcelandFaeroe Ridge: Marine Geophys. Research, v. 1, p. $328-351$.

Bottinga, Y., 1973, Thermal aspects of sea-floor spreading, and the nature of the oceanic crust: Tectonophysics, v. 18, p. $1-17$.

Bowin, C. O., 1973, Origin of the Ninetyeast Ridge from studies near the equator: Jour. Geophys. Research, v. 78 ,p. 6029-6043.

Bryan, G. M., and Simpson, E.S.W., 1971, Seismic refraction measurements on the continental shelf between the Orange River and Cape Town, $m$ Delany, F. M., ed., The geology of the east Atlantic continental margin, SCORIUGS symposium on east Atlantic continental margins: Inst. Geol. Sci. Rept., no. 70:16.

Burke, K. C., and Wilson, J. T., 1972, Is the African plate stationary?: Nature, v. 239, p. $387-390$.

Burke, K. C., Kidd, W.S.F., and Wilson, J. T., 1973, Relative latitudinal motion of Atlantic hot spots: Nature, v. 245 , p. $133-137$.

Dehlinger, P., 1969, Gravity and its relation to topography and geology of the Pacific Ocean, in Hart, P., ed., The Earth's crust and upper mantle: Am. Geophys. Union Geophys. Mon. 13, p. 352-363.

Dickson, G. O., Pitman, W. C., III, and Heirtzler, J. R., 1968, Magnetic anomalies in the South Atlantic and ocean floor spreading. Jour. Geophys. Research, v. 73, p. 2087-2100.

Dietz, R. S., and Holden, J. C., 1970, Reconstruction of Pangea: Break-up and dispersion of the continents, Permian to present: Jour. Geophys. Research, v. 75, p. $4939-4956$

Du Plessis, A., Scrutton, R. A., Barnaby, A., and Simpson, E.S.W., 1972, Shallow structure of the continental margin of southwestern Africa: Jour. Marine Geology, v. 13, p. $77-89$.

Ewing, M., Le Pichon, X., and Ewing, J., 1966, Crustal structure of the mid-ocean ridges 4 Sediment distribution in the South Atlantic Ocean and the Cenozoic history of the Mid-Atlantic Ridge: Jour. Geophys. Research, v. 71, p. 1611-1635.

Faust, L. Y., 1951, Seismic velocity as a function of depth and geologic time: Geophysics, v. 16, p. $192-206$.

Francheteau, J., 1970, Paleomagnetism and plate tectonics: Califomia Univ., Scripps Inst. Oceanography Marine Phys. Lab. (S.I.O. ref. 70.30$), 345 \mathrm{p}$

Francheteau, J., and Le Pichon, X., 1972, Marginal fracture zone as structural framework of continental margins in the South Atlantic Ocean: Am. Assoc. Petroleum Geologists Bull., v. 56, p. 991-1007.

Goslin, J., Beuzart, P., Francheteau, J., and Le Pichon, X., 1972, Thickening of the oceanic layer in the Pacific Ocean: Marine Geophys. Research, v, 1, p. 418-427.

Goslin, J., Mascle, J., Sibuet, J. C., and Hoskins, H., 1974, Geophysical study of the easternmost Walvis Ridge, South Atlantic: Morphology and shallow structure: Geol. Soc. America Bull., v. 85, p. 619-632.

Grau, G., 1969, Sources sismiques pour l'océanographie: Inst. Français Pétrole Rev., v. 24, no. 9, p. 1007-1028.

Gunn, R., 1943, A quantitative study of the isobaric equilibrium and gravity anomalies in the Hawaiian Islands: Franklin Inst. Jour., v. 236, p. 373-390.

Hatherton, T., 1967, A geophysical study of the Nelson-Cook Strait region, New Zealand: New Zealand Jour. Geology and Geophysics, v. 10, p. 1330-1347.

Hekinian, R., 1972, Volcanics from the Walvis Ridge: Nature, v. 239, p. 91-93.

1975, Petrology of the Ninetyeast ridge (Indian Ocean) compared to other aseismic ridges: Marine Geology (in press).

Houtz, R., Ewing, J., and Le Pichon, X., 1968, Velocity of deep sea sediment from sonobuoy data: Jour. Geophys. Research, v. 73, p. $2615-2641$

Jobert, G., 1973, Ondes en milieu élastique isotrope héterogène, in Coulomb, J., and Jobert, G., eds., Traité de géophysique interne, Vol. 1, Sismologie et pesanteur: Paris, Masson, $646 \mathrm{p}$.

Ladd, J. W., Dickson, G. O., and Pitman, W. C., III, 1973. The age of the South Atlantic, in Nairn, A.E.M., and Stehli, F. G., eds., The ocean basin and margins: The South Atlantic: New York, Plenum Pub. Corp., 550 p.

Le Pichon, X., 1968, Sea-floor spreading and continental drift: Jour. Geophys. Research, v. 73, p. $3661-3697$

- 1969, Models and structure for the oceanic crust: Tectonophysics, v. 7 , p. $385-401$

Le Pichon, X., and Hayes, D. E., 1971, Marginal offsets, fracture zones and the early opening of the South Atlantic: Jour. Geophys. Research, v. 76, p. 6283-6296.

Le Pichon, X., Francheteau, J., and Bonnin, J., 1973, Plate tectonics: Amsterdam, Elsevier, $300 \mathrm{p}$.

Leyden, R., Brian, G., and Ewing, M., 1972. Geophysical reconnaissance on African shelf: 2, Margin sediments from Gulf of Guinea to Walvis Ridge: Am. Assoc. Petroleum Geologists Bull., v. 56, p. 682-693.

Lucas, W. H., 1971, Gravity anomalies and their relation to major tectonic features in the North Central Pacific: Natl. Oceanog. and Atmos. Admin. Tech. Rept. ERL 214-POL 6 CIS, $19 \mathrm{p}$

Mascle, J., and Sibuet J. C., 1974, New pole for the early opening of South Atlantic: Nature, v. 252 , p. $464-465$

Matthews, D. J., 1939, Tables of the velocity of sound in pure water and sea water for use in echosounding and sound ranging: London, Hydrographic Dept.

Maxwell, A. E., Von Herzen, R. P., Hsü, K. J. Andrews, J. E., Saito, T., Percival, S. F., Milow, E. D., Jr., and Boyce, R. E., 1970a Deep sea drilling in the South Atlantic: Science, v. 168 , p. $1047-1059$.

Maxwell, A. E., and others, $1970 \mathrm{~b}$, Initial re ports of the Deep Sea Drilling Project. Vol. III: Washington, D.C., U.S. Govt. Printing Office, $806 \mathrm{p}$.

Molnar, P., and Atwater, T., 1973, Relative mo- tion of hot spots in the mantle: Nature, $v$ 246 , p. $288-291$

Morgan, W. J., 1971, Convection plumes in the lower mantle: Nature, v. 230 , p. 42-48.

-1972a, Plate motions and deep mantle convection, in Shagam, R., and others, eds. Studies in earth and space sciences: Geol. Soc. America Mem. 132, p. 7-22.

1972b, Deep mantle convection plumes and plate motions: Am. Assoc. Petroleum Geologists Bull., v. 56, p. 203-213.

Palmason, G., 1971, Crustal structure of Iceland from explosion seismology: Reykjavik, Soc. Scientiarum Islandica, $187 \mathrm{p}$.

Pastouret, L., and Goslin, J., 1974, Middle Cretaceous sediments from the eastern part of Walvis Ridge (South Atlantic): Nature, v. 248 , p. $495-496$

Sclater, J. G., and Detrick, R., 1973, Elevation of midocean ridges and the basement age of JOIDES deep sea drilling sites: Geol. Soc America Bull., v. 84, p. 1547-1554.

Siedner, G., and Miller, J. A., 1968, K-Ar age determinations on basaltic rocks from Southwest Africa and their bearing on continental drift: Earth and Planetary Sci. Letters, v. 4, p. 451-458

South Africa Geological Survey, 1963, Geological map of South West Africa, showing mineral occurrences and gravity contours (Bouguer anomalies): Pretoria and Cape Town, South Africa, Govt. and Stationery Office, scale $1: 1,000,000$.

Talwani, M., and Heirtzler, J. R., 1964, Computation of magnetic anomalies caused by two dimensional structure of arbitrary shape, in Parks, G. A., ed., Computers in the mineral industries: Stanford, Calif., Stanford Univ. Press, p. 464-480.

Talwani, M. Worzel, J. L, and Landisman, M. 1959, Rapid gravity computations for two dimensional bodies with application to the Mendocino submarine fracture zone: Jour. Geophys. Research, v. 64, p. 49-59.

Uchupi, E., 1971, Bathymetric atlas of the Atlantic, Caribbean, and Gulf of Mexico: Woods Hole Oceanographic Inst. Ref. 71-72, 12 p.

Vening Meinesz, F. A., 1941, Gravity over the Hawailan archipelago and over the Maderia area: Netherlands Acad. Proc. Wetensia, $44 \mathrm{p}$

Walcort, R. I., 1969, Flexure of the lithosphere at Hawaii: Tectonophysics, v, 9, p. 435-446.

Watts, A. B., and Cochran, J. R., 1974, Gravity anomalies and flexure of the lithosphere along the Hawaiian-Emperor seamount chain: Royal Astron. Soc. Geophys. Jour., v. 38 , p. $119-141$.

Wilson, J. T., 1965, Submarine fracture zones, aseismic ridges and the ICSU line: Proposed western margin of the East Pacific Rise: $\mathrm{Na}$ ture, v. 207 , p. 907-911.

1973, Mantle plumes and plate motions Tectonophysics, v. 19, p. 149-164.

Worzel, J. L., 1965, Pendulum gravity measurements at sea (1936-1959): New York, John Wiley \& Sons, $422 \mathrm{p}$.

Manuscript Received by the Society MaRch 12,1974

Revised Manuscript Received December 10, 1974

MANUSCRIPT ACCEPTED MARCH 17, 1975

Contribution No. 254, Departement Scientifique du Centre OcéanoLOGIQUE DE BRETAGNE 